\title{
The Implementation of Spiritual Education Program among the Malaysian Armed Forces Personnel
}

\author{
Burhanuddin Jalal ${ }^{1 *}$, Zainurin Abdul Rahman ${ }^{2}$, Ismail Sheikh Ahmad ${ }^{2}$, \\ Kamal Basha Madarsha ${ }^{2}$, Johary Othman ${ }^{2}$, Mohd Sahari Nordin ${ }^{2}$ \\ ${ }^{1}$ Faculty of Defence Studies and Management, National Defence University of Malaysia, \\ 57000 Kuala Lumpur \\ ${ }^{2}$ Faculty of Education International Islamic University of Malaysia, \\ 53100 Kuala Lumpur \\ ${ }^{*}$ Corresponding Author \\ Email: burhanuddin@upnm.edu.my
}

DOI: 10.6007/IJARBSS/v7-i8/3255 URL: http://dx.doi.org/10.6007/IJARBSS/v7-i8/3255

\begin{abstract}
The strength of the military organization can be measured through three important elements which are the firing power, mobility power and combat power. The aspect of the fighting spirit encompasses the aspect of the spiritual readiness, a fundamental element that needs to be consolidated within all Malaysian Armed Forces personnel's. It has to stay at the top level and they have to be constantly ready in defending the sovereignty of the state. The readiness of the military institutions is not only assessed in terms of asset equipment and sophisticated tools, but even more important, is the spiritual value within every military member, especially in terms of self-readiness to shoulder the responsibility and mandate of the country. In this matter, KAGAT or Kor Agama Angkatan Tentera Malaysia (Malaysian Armed Forces Religious Corps), through the Malaysian Armed Forces Islamic Spirituality and Mental Construction Policy , which has covered various Islamic education and spiritual activity programs to every layer of the MAF organization, has introduced a spiritual education program for personnel's of the Malaysian Armed Forces (MAF). The focus of the study is to make an early assessment on the program implementation from the aspect of planning, implementation and also monitoring through the perspectives of the MAF personnel's. The study methodology involves the mixedmethod, namely the qualitative and the quantitative methods and 1,137 respondents had been involved. The study findings also show that there is a close relationship in terms of the environment, benefit, teacher and the preacher (members of KAGAT), and also the members' attitude towards the program. The study findings also show that spiritual strength has a positive relationship towards the readiness and the fighting strength of the Malaysia Armed Forces. Indeed, the Islamic education also dacwah efforts carried out by the Malaysian Armed Forces Religious Corps should further be strengthened so that the spiritual readiness of the Malaysian Armed Forces personnel's gets to be increased to ensure that they always fulfil two main aspects concerned- the combat power as the physical aspect and the spirituality so we shall have a credible line of quality and excellent soldiers. The impact of this research will
\end{abstract}


strengthen the opinion that the basic Islamic education is a platform launcher for Malaysian Armed Forces Religious Corps to intensify the efforts of religious education systematically and efficiently.

Keywords: Spirituality, Readiness, Spiritual education, Military

\section{INTRODUCTION}

The preparation for a strong team of soldiers, who are both professional and credible is not habitual, in itself. It does not imply that there are enemies or threats that have propelled a country to have to form a body of army which may see as the answer to issues pertaining to national security and defence. In actual fact, the formation of a military force in a particular country especially in countries dominated by Muslims, is something that has been decreed by Allah SWT. He has dictated this in the Quran, in al-Anfal verse 60 which means: "And make ready against them all you can of power, including steeds of war (tanks, planes, missiles, artillery, etc.) to threaten the enemy of Allah and your enemy, and others besides whom, you may not know but whom Allah does know. And whatever you shall spend in the Cause of Allah shall be repaid unto you, and you shall not be treated unjustly".

Based on the verse above, Islamic enemies will prevail whether they are within our knowledge or outside our knowledge. This is why Allah commands Muslims to get prepared and to be careful as to face any possibilities so that they will not be in shock when uninvited enemies come to attack. The importance of the Malaysian Military Force as a highly mandated organisation when it comes to defending the country has been affirmed by one of our former Prime Ministers of Malaysia, Dato' Seri Mahathir Mohammad (BTDM, 2002) in the recruits' end-of-training speech on 31 December 2001 where he states, "The country owes it to the military forces who have fulfilled their duties in full loyalty and are willing to sacrifice to ensure that the country is safe and free from any form of threats since the World War 2. Thus, as the citizens we must stay united with the soldiers in sustaining peace so that we will not become slaves to the colonisers once again".

In the effort to form a formidable and intimidating military front, we should know how to choose a really capable formula in producing members who are efficient and have credibility. Some training aspects like disciplining the members, training members to develop weaponhandling skills, forming morality among them so that they will obey the rules and commands, working hard and staying away from any form of abuse are things that should be given the priority. However, the success of these aspects cannot be fully anticipated without one more important element in the members' self-development and formation. The element would be the element of 'spirituality' that is related to faith, belief, and piety towards the religion.

The importance of the consolidation of these spiritual values should further be stimulated to ensure that the servants of the Malaysian Military Force are able to perform their duties efficiently and effectively. General Tan Sri Dato' Seri Zulkifli Zainal Abidin Malaysian Chief of Army, in his first command speech in his appointment as Malaysian Army Chief asserts "In the 
context of training in the Army Force, and to build human professionalism and development, spiritual-oriented training must be prioritised. This aspect is important to strengthen the platform of the training to be more effective". To ensure that the whole organisation can be formed and educated, an ongoing construction process through a systematic training is vital. According to Muhammad Ahmad Bashil (1989) in his book, Politics and military - the Hudaibiyyah Agreement, he explains that, the efforts to form soldiers who can understand their duties effectively, and at the same time who become the loyal servants of Allah, require continuous efforts of dakwah and proper education.

Statements clearly demonstrate that the knowledge of aqidah, syariah and moral is important to each and every member of the Malaysian Armed Forces, in eliminating the negative influence of secularism and to help them become pious Caliphs of Allah. Therefore, the Armed Forces' Religious Corps or KAGAT has been given the duty, role and responsibility to build the religious appreciation and spirituality among the members of the Malaysian Armed Forces.

The mental and spiritual construction policy of the Malaysian Armed Forces gazetted through the Malaysian Armed Forces Council No: 9/91 or Dasar Pembinaan Mental dan Kerohanian Islam (DPMKI-9/91), has been MAF's constructive effort through the Malaysian Armed Forces Religious Corps or Kor Agama Angkatan Tentera Malaysia (KAGAT) to ensure that every member of MAF is given some religious input to be understood, empathised and practised. The main core of this policy is the construction of mental and spiritual endurance through knowledge of fardu ain and fardu kifayah. This is compared to the stress given to the strength of weaponry and physicality that have long become the mainstay of the military domain.

This study is done as one of the early efforts to see the effectiveness of the program after its implementation since 1991. This study is regarded as an initial work due to its small scope and the fact that it covers MAF personnel's who happened to be residing in the Klang Valley. The main focus of this study is the assessment done on the effectiveness of DPMKI-PMAT 9/91 in terms of the planning, implementation and monitoring through the perspectives of the MAF personnel's on the strengths and weaknesses of the DPMKI-PMAT 9/91.

\section{THE ISLAMIC SPIRITUALITY AND MENTAL CONSTRUCTION PROGRAM}

In the effort to provide a more consolidated Islamic education and understanding to every Malaysian citizen who are Muslims, and who are in the Malaysian Armed Forces, KAGAT has worked on a policy named The Islamic Spirituality And Mental Construction Policy. Through this policy, every Muslim personnel's of the Malaysian Armed Forces would be involved. In a year, every member is made compulsory to receive Islamic education and program totalling 857 hours for the purpose of constructing their Islamic mental and spiritual state through some prescribed guidance issued from time to time (PMAT 9/91).

Through this gazetted policy, there are two forms of construction presented in this policy as an addition to the existing physical training policy, seeking to produce soldiers who have physical, 
mental and spiritual strengths. The form of the construction is set for the MAF members to master the following areas:

a. Mental endurance, through the inclusion of Islamic knowledge covering knowledge's of fardu ain and fardu kifayah.

b. Strong spiritual training endurance and precise and valid understanding of Islamic practices.

The Efforts Of KAGAT In Building The Spiritual Fighting Strength Among The MAF Personnel's As has been explained previously, the strength of an Army personnel's can be built from various aspects of strength. By language 'strength means: 'Energy, force, power, formidability. Fighting means 'to struggle, to be at war'. Meanwhile, 'spiritual' means: 'something about the soul, spiritual by nature, spirituality (Kamus Dewan 2005).

In terms of the terminology, spiritual combat power means: "Elements related to the soul or spirituality that becomes the motivator in the fight or war, to achieve the aim intended". In other words, it can also be defined as: The spiritual strength or the hidden strength that exists in the soldier, which is able to propel him to persevere and to be brave and bold in surviving any kinds of struggle, hardship and danger, although the pressure of the war may get intensifying, and this is again reiterated by Fazlur Rahman (1990), "A secret power that exists within military personnel which acts as a 'driving force' to keep them steadfast and courageous in any kind of hardship, difficulty, or danger, despite the increased degree of pressure during battle."

A soldier who has good quality requires a clear fulfilment in terms of the physical, mental and spiritual aspects. The physical strength will guarantee good mobility and swift action, especially during operations and at war. The mental strength, on the other hand, stands as the determinant to one's endurance in facing stress (combat stress) and similar circumstances. Spiritual strength would warrant one's spiritual combat power in operations and training, simultaneously creating a formidable wall of defence.

\section{The Importance of the Spiritual Combat Power}

The spiritual combat power is seen to be of utmost importance in rendering success to a war mission even an organisation's cause. Kennedy dan Hugh (1986) pointed out: "Lately, the concern of the big corporation toward ethical and even spiritual aspect of their employee has grown rapidly, in the global market in the future, you will find saint mystics or Sufis in the big corporation or modern organization, not in the vicars, monasteries, synagogue's, temples, church or mosques".

Spiritual combat factor is identified as an important factor when linked with the defence power or strength based on the following aspects:

a. Spiritual Combat Power As The Basis and The Main Asset of the Formation of Power of a Defence Force: Military knowledge has asserted that the strength of a defence force is created 
based on five main factors, namely, the capability of a fighter, adequate (logistics) equipment, discipline, spiritual Strength (power) and teamwork (esprit de corps).

b. Spiritual Combat Power As an Absolute Power. It means, the spiritual power is an inner element that becomes the beacon of absolute strength that can determine one's success or failure in his or her struggle or fight. This is because, in the battlefield, only the spiritual strength will produce the real bravery and willingness to move on to the front line. Soldiers who have the spiritual combat power will continue fighting to the end. The spiritual strength is very much needed to retain the combat power of soldiers. Fights guided by such strength is a form of healer that can rescue people who are sick or ill, and further ensure their good health and wellbeing.

c. Spiritual Combat Power As A Catalyst to Victory. Ahmad Gulzar (1986) in his book The Battle of the prophet of Allah had noted the conviction of Field Marshal Montgomery where he stated that the spiritual power is the most important element that determines a soldier's excellence in the battlefield. He further explained, "Spiritual strength is that fighting spirit which is considered to be the first of the vital factors for success in battle, because in it reflected all the attributes which should be found in military personnel, including character, discipline, courage, truthfulness, ability and capacity to face difficult conditions, and which prevents the loss of faith or motive for struggle."

\section{RESEARCH OBJECTIVES}

The objectives of the study are as follows:

a. To assess the extent of the effectiveness of the implementation of the spiritual education program through the DPMKI-PMAT 9/91 program.

b. To assess how far the DPMKI-PMAT 9/91 program can build the spiritual fighting strength of the MAF members.

c. To identify the strength and weakness of the implementation of the DPMKI-PMAT 9/91 program.

d. To suggest solutions to the problem and any improvement that can serve as the policy for MAF services.

\section{RESEARCH METHODOLOGY}

The methodology of this study involves the mixed-method using both the qualitative and the quantitative methods. It seeks to obtain a more systematic, precise and profound data. The qualitative and quantitative findings shall be used as the basis to answer the study questions, whereas in certain circumstances, the qualitative findings are used to describe about the quantitative findings in more detail. In general, the quantitative data are obtained through the filling in of survey forms, and the quantitative data obtained through interviews. The population of the study comprises of 1,137 MAF personnel's from $1^{\text {st }}$ Batalion of Royal Malay Regiment, Army Institute of Electrical Mechanical Engineering Corps and 73 Royal Signal Corps. This study involves two sample categories, namely the quarantine survey sample of 279 respondents and the qualitative interview sample totalling 31 respondents. 


\section{FINDINGS}

For the purpose of the presentation of this paper work, its will only focus on the study findings report on issue, which is the aspect of the perceptions of the members towards the enhancement of spiritual strength following the DPMKI-PMAT 9/91 program, especially in terms of the attitude based on 10 items listed in the program. The findings based on gender, rank and marriage are as follows:

a. The Average of $\mathbf{1 0}$ items for the Enhancement of Spiritual Strength (Gender). Diagram 1 demonstrates a uniform result, where the highest average for both gender is on the item 'tahlil or motivation ceremonies motivate me towards religious concerns". Meanwhile, low average is on the item "qiamullail or mid-night worship increases self-motivation". As the average for all 10 items exceeds the score of 4.0 , it can be concluded that the perceptions on spiritual strength is high. (increased).

\section{Diagram 1: The Average of 10 items for the Enhancement of Spiritual Strength (Gender)}

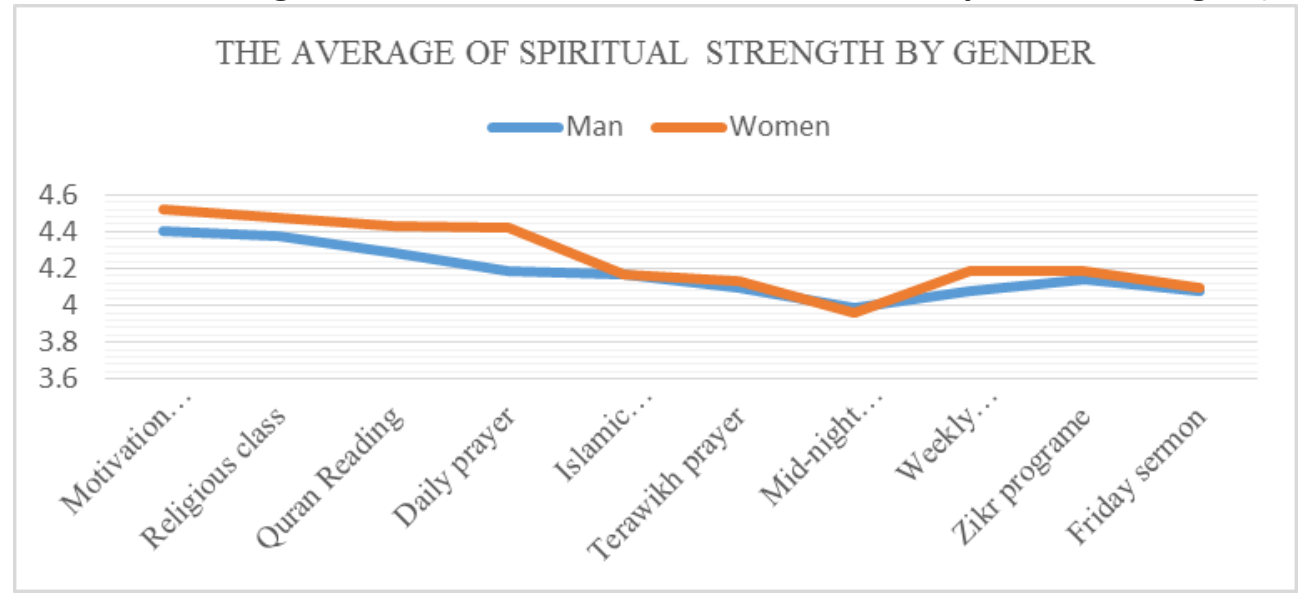

b. The Average of $\mathbf{1 0}$ items for The Enhancement of Spiritual Strength (Rank) Diagram 2 illustrates 10 items based on rank and the results have been quite interesting. The average score for the highest officer is for the item 'Tahlil ceremonies increase my spiritual strength', whereas the highest score for LLP is the item "Tahlil or motivation ceremonies draw me to religious issues and concerns'. Meanwhile, the lowest average for officers is the item 'the substance of Islamic events has given me some positive awareness' and LLP is 'Qiamulail or mid-night worship increases my self-motivation'.

\section{Diagram 2: The Average of 10 items for The Enhancement of Spiritual Strength (Rank)}


THE AVERAGE OF SPIRITUAL STRENGTH BY RANK

Officer $\longrightarrow$ Other Rank

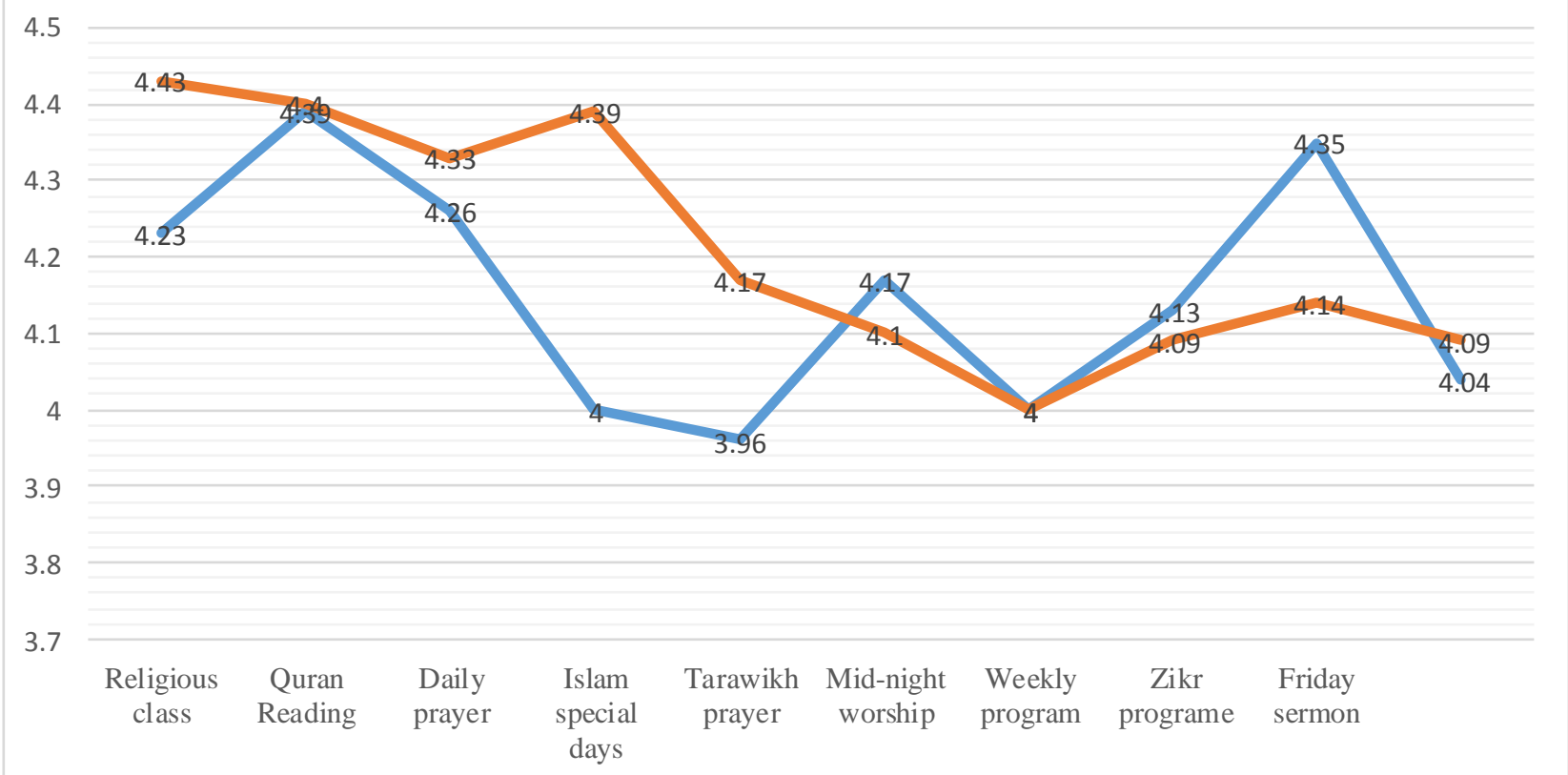

c. The Average of $\mathbf{1 0}$ items for The Enhancement of Spiritual Strength (Marriage). In Diagram 3 we are presented with some findings on the enhancement of spiritual strength by marriage. There is a similarity between the status of married and bachelor, showing similar results, but the status of divorced shows a very low average score for two items (tahlil gatherings increase my spiritual strength and Qiamulail or mid-night worship increases my self-motivation).

\section{Diagram 3: The Average of 10 items for The Enhancement of Spiritual Strength (Marriage)}

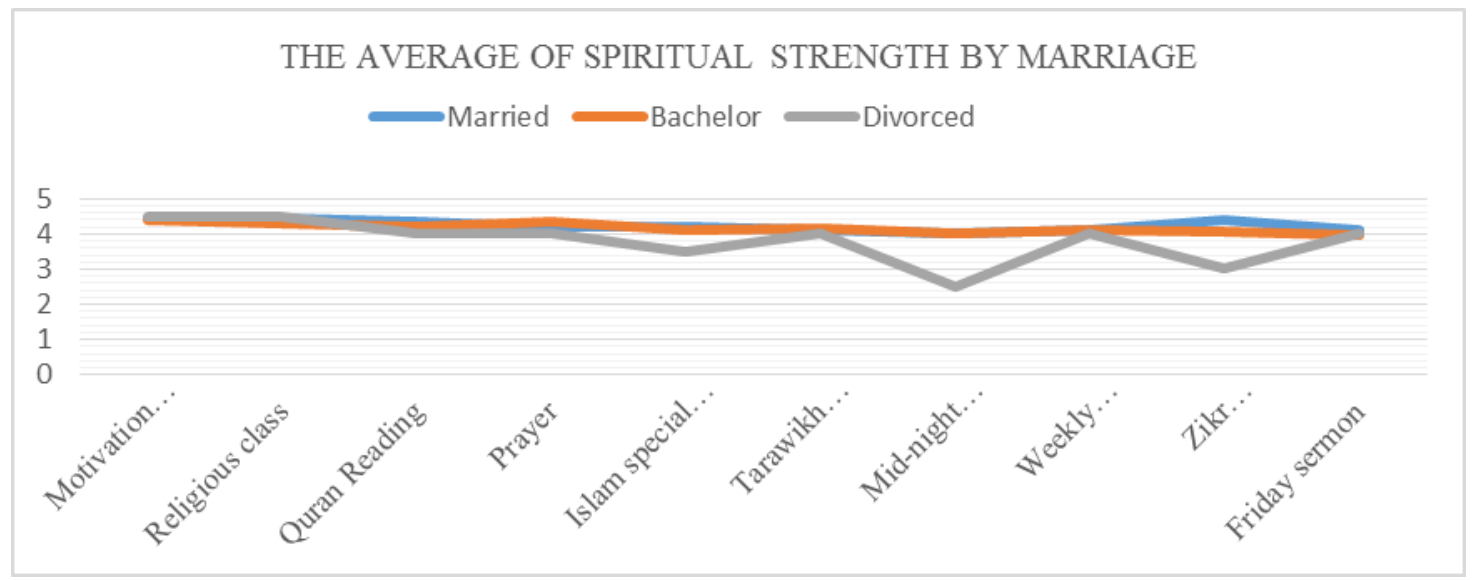


Other than that, there are also several fascinating main findings gathered from the quantitative analysis:

First: There exists the relationship between several study elements, such as the environment, benefits, coach and attitude. All these four elements are found to have a positive and significant relationship with effectiveness of DPMKI-9/91.

Second: The linear regression analysis shows that attitude is one of the predictors for the fardu ain score. In other words, attitude can well determine an MAF personnel's level of religious knowledge.

Third: The study findings show that there are three aspects that influence the combat strength which are the fighting spirit or jihad, mental strength and activities while on duty in the camp. Meanwhile, the spiritual strength is found to have a positive relationship with the combat strength. This demonstrates that the level of spiritual strength must be given due attention among MAF members.

Fourth. Two activities found to be able to form positive attitude towards the DPMKI-9/91 program and which will be able to add to the effectiveness of the program is the tahlil, which is carried out every Friday night, and also religious classes.

It is also worth explaining that the study findings from the qualitative aspect have established several main findings. They are:

First: DPMKI-9/91 Program has successfully left a great impact to the MAF members, in terms of the enhanced spiritual development among Muslim personnel's since its inception in 1991. This program should be continued and empowered, as it is able to develop the interest for the members to learn more about, and practice, Islam among the MAF personnel's.

Second: There are several major shortcomings that need to be addressed, such as the approach and implementation of the DPMKI-9/91 program, the Islamic education syllabus for the MAF, skill training for the trainer/ personnel's of KAGAT, teaching method, better facilities, positionfilling, increased position grades, the need to increase the number of woman-educators, the use of teaching and learning aids, the coordination of the program schedule and the aspect of financial allocation.

Third: The aspect of supervision, monitoring and cooperation from all parties are crucial to render this DPMKI-9/91 program a success.

\section{CONCLUSION}

From this study, particularly in the aspect of spiritual strength and Islamic appreciation among respondents, it reflects that there exists a close relationship between all aspects of Islamic appreciation. According to Hassan Langgulung (1987), Islamic values that exist in a person have two functions which are mutually dependent on each other, namely as a result of learning process and also part of that learning process. At the same time, the appreciation of Islam in a particular aspect also affects the appreciation of Islam in other aspects.

Based on this study, it is clear that members of Malaysian Armed Forces already have a good foundation in appreciating Islam and this must continue to be maintained and further 
enhanced. Dakwah efforts by Armed Forces Religious Corps should continue to be strengthened and reinforced. The aspect of the strength of dua and the practice of ibadah should be established in accordance with the sophistication of weapons and the strength of the soul and the heart so that a perfect balance can be achieved with mental and physical strength. Allah SWT decrees in Surah an-Anfal verse 45 which provides guidance towards achieving success while facing the enemy. Allah said, (al-Anfal 8: 45), which means: "O you who have believed, when you encounter a company [from the enemy forces], stand firm and remember Allah much that you may be successful.

Overall, this paper discusses the aspect of appreciation of Islam and spiritual strength among members of Malaysian Armed Forces. Based on the results of the study, the level of appreciation of Islam as a whole is high but there are areas of weaknesses that need to be improved. This is due to the fact that thorough appreciation of Islam requires the fulfilment of all aspects including tasawwur, feelings and behaviour. In this matter, Mustaffa Masyhur (1995) explains that the act of appreciating Islam requires the achievement of certain level, starting from understanding Islam in its true manner, precise as being delivered by Rasulullah (s.a.w), to the extent that all teachings are practiced correctly and perfectly, similar to the level achieved by amilin and solihin. The peak of one's appreciation of Islam among the most ordinary Muslim individuals (general mass) is to be a soleh individual who understands and embraces the principles of Islam, demonstrates obedience in practicing the syara' humbly for Allah SWT, in terms of following His orders, as well as avoids His prohibitions in all aspects of life, in both secular and religious contexts.

All in all, based on the study, the DPMRI-PMAT 9/91 program should be continued with several improvement plans so that religious values can be stengthened among the MAF members, to create a line of personnel's who have the 3M traits, Muslim, Mukmin and Muhsin and who possess the 'spiritual combat power'. Apart from that, the preaching (da'wah) efforts by the Malaysian Armed Forces Religious Corps must be made robust, in line with the sophistication of our weaponry and the formidability of their hearts and souls balanced with their physical and mental strengths. Allah (s.w.t.) in the Chapter of an-Anfal verse 45 had granted the guidance for us to succeed upon facing our enemies. In the Chapter of al-Anfal (8: 45) $O$ ye who believe! when ye meet a force be firm and call Allah in remembrance much (and often); that ye may prosper. And obey Allah and His Messenger; and fall into no disputes, lest ye lose heart and your power depart; and be patient and persevering: for Allah is with those who patiently persevere".

\section{ACKNOWLEDGMENTS}

This work was supported by NDUM under Short-Grant Scheme No GPJP/SSK/11-2015.

\section{REFERENCES}

Baseimeih, A. (1987). Al-Quran al-Karim dan Tafsir pimpinan Al-Quran kepada pengertian AlQuran Ar-Rahman Edisi ke lapan. Kuala Lumpur: Department of Islamic Affairs, Prime Minister's Office, Malaysia.

Ali, A.Y. (1995). The Meaning of Holy Quran. Kuala Lumpur: A. S Nordeen Publication. 
Rahman, A. (1990). Muhammad: Unique Military Leader. Translated. Shah Alam: Hizbi Publication.

Rahman, A. (1996). Indeks al-Quran Translation. Yusuf Ismail. Kuala Lumpur: A. S Nordeen Publication.

Ahmad Gulzar. (1986). The Battle of the Prophet of Allah. Lahore: Islamic Publication.

Raba, A. (2001). Major Personalities in the Quran. Kuala Lumpur: A. S. Noordeen.

Baba, A. (1997). Statistik Penyelidikan Dalam Education Dan Sosial Sains. Bangi: Publisher of Universiti Kebangsaan Malaysia.

Babie, E. (1922). The Practice of Social Science Research. 6 Edition. California: Waddsworth.

Jalal, B. (1996). Dasar pembinaan mental dan kerohanian Islam. Jurnal Sorotan Darat. Kuala Lumpur: Malaysian Army Training Department . No: 30 December.

Jalal, B. (1998). KAGAT: Wadah dan Profesionalisme. Jabatan Arah Kor Agama Markas Angkatan Tentera. Kuala Lumpur: Ministry of Defence, Malaysia.

Cartes, W. M. (1985). A Practical Guide To Educational Research. New Jersey: Prentice Hall.

Chua, Yan Piaw. (2006). Asas Statistik Penyelidikan 11. Kuala Lumpur: Mc Graw-Hill.

Chua, Yan Piaw. (2006). Kaedah Dan Statistik Penyelidikan 1. Kuala Lumpur: Mc Graw Hill.

Hassan Langgulung. (1987) Pendidikan Islam Menghadapi Abad 21. Shah Alam: Hizbi.

Kennedy, Hugh. (1986). The Prophet And The Age Of The Caliphates: The Islamic Near East From The Six To Eleventh Century. London: Longman.

Mashhur, Mustafa. (1995). Min Fiqh Al-Da'wah: Tariq Al-Da'wah . Jil. 1. al-Qahirah: Dar alTawzi'wan al-Nasyr al-Islamiyyah.

Bashil, M.A. (1989). Politik dan Ketenteraan - Perjanjian Hudaibiyyah. Kuala Lumpur: Dewan Pustaka Fajar.

Teuku Iskandar et al. (2015). Kamus Dewan. Kuala Lumpur: Dewan Bahasa dan Pustaka.Abdul Monir Yaacob.(2012). Islam dan Kebebasan Beragama Menurut Perlembagaan Persekutuan. Kuala Lumpur: Technologic Trading Sdn Bhd. 